\title{
The Impact of Parental Attitudes on Problem Solving Skills in High School Students
}

\author{
Rasim Tösten ${ }^{1}$, Bünyamin Han ${ }^{2, *}$, Sabri Anik \\ ${ }^{1}$ Department of Physical Education, Siirt University, Turkey \\ ${ }^{2}$ Department of Education Faculty, Dicle University, Turkey \\ ${ }^{3}$ Social Sciences Institute, Siirt University, Turkey
}

Copyright $\mathrm{O} 2017$ by authors, all rights reserved. Authors agree that this article remains permanently open access under the terms of the Creative Commons Attribution License 4.0 International License

\begin{abstract}
Problem solving skill is one of the important skills which are expected to be gained during the educational programs. In the development of children's skills and shaping the behaviors, parental attitudes are believed to be effective. That means problem-solving skills and behavioral characteristics of individuals are closely related. From that starting point this research aims at revealing the impact of parental attitudes on problem solving skills of high school students. The research is in quantitative method with relational survey model. The working group of the study is 326 high school students selected randomly from Silvan district in 2015. For the analysis of data, descriptive statistical techniques (frequency, percentage, mean, and standard deviation), cross-correlation and regression analysis were used. Some of the important results of the study are: The level of students' problem solving skills is medium, there is no significant relationship between authoritarian attitudes of mothers and problem-solving skills of high school students, there is a positive medium level relationship between democratic attitudes of parents and problem-solving skills of students, parental attitudes of students predict $20 \%$ of students' problem solving skills.
\end{abstract}

Keywords Parental Attitudes, Problem-solving Skills, High School Students

\section{Introduction}

People with a social presence, are in the process of learning throughout life beginning from the birth until the death. The efficiency of this period depends on factors that affect the individual. Individuals who are in constant interaction with the environment are affected mostly by families [1]. Educators emphasize that parental attitudes have a significant impact on the child's behaviors. Starkey and Klein [2] state that children are more successful in school activities as a result of regular and meaningful parental interests. The attitudes of parents have a great importance on the student's personality and characteristics. Complementary behaviors demonstrated in school and family enable great benefits on students' education and socialization [3]. Individual's first training starts in the family and continues in school. The cases will be effective during the critical periods of life take place mostly in these two environments. As a result of parental neglect serious problems may occur in students' fundamental, physical and psychological needs that affect their health and development negatively $[4,5]$.

Family environment is very important in children's education. The impact of family on child's education can vary depending on the parents' behavior style. The first place where individual's all developmental fields are shaped is near environment [6]. One of the most important environmental factors in shaping the personality is parental attitudes [7]. Also the attitude of parents is effective in children's psycho-social development [4]. Parental attitudes seem to have a great influence on all the mentioned developments of the child. In this regard, protective, democratic, flexible and strict or rejectionist parental attitudes in raising their children will affect child's skills in many ways. Furthermore, there are many features that affect parental attitudes such as; the relationship between parents and children, family environment where the child grew up, the relationship between parents, the child's being suitable for their expectation, number of children, the child's gender and characteristics features, the family's socioeconomic status and cultural features $[8,9,10]$.

There are several approaches related to types of parental attitudes, however, they are basically democratic parental attitude [11,10], protective parental attitude [12,7], authoritarian parental attitude [13]. Democratic parents are interested in their children, meet their needs and desires with the tolerance, provide an opportunity to express themselves. These parents know that each child has a unique developmental capacity, so they allow children develop freely, reveal talents and self-realization [14]. Authoritarian 
parents show more conditional approach towards their children. They impose their wishes instead of children's interests, wishes and needs, which disturbs the children. The authoritarian parental attitude prevents independent personality development in children, increases the level of aggression especially in boys and reduces the level of self-esteem [15]. Prevention situations and limitations which are unsuitable for the children's developmental levels, affect adversely the individual's psychological situation, communication, social relationships and also concentration in school. Protective parents apply extreme conservation measures and supervision on their children, which causes loss of self-confidence and entrepreneurship. By interfering unduly in every respect, they prevent children from becoming self-sufficient and from learning to trust themselves [4, 5]. When faced with different situations, individuals who are not self-sufficient will become inadequate in their own decisions.

Behavioral characteristics of individuals are closely related to problem-solving skills. Especially high school students are in the critical period in terms of developmental stages. They should be enabled suitable school and family environments where they can solve their possible problems and can develop their own solutions without installing the disadvantageous period. There are 6 concepts in the problem solving model developed by Fuson, Hudson and Pillar (1997); understanding the problem context, understanding the preliminary information in the problem, the enrichment of the understanding by thinking given data mathematically, making the solution plan, implementation of the solution and evaluation of the solution (cited in [16].

One of the important skills which are expected to be gained by the students is problem solving skill. Among the skill component expressed as 21 st century skills, problem solving skills occupy an important place. According to Jencks et al [17] family characteristics is the most important environmental factor in achieving the objectives of the program by students. Extreme, dull or wrong parental attitudes may cause negative behaviors in the development of children. According to a study [18], more than half of the school achievements are resulted from the family support. The children who have parents showing close attention to the child, planning the working conditions of children, supporting the success of child with laudatory words, encouraging children in the failure by saying "if you try you will succeed" are more successful [19]. Therefore, parental attitudes are believed to be effective in the development of children's many skills and in shaping the behaviors.

\section{Purpose of the Study}

This research aims to reveal the effect of parents' attitudes on problem-solving skills of high school students. In the research following questions will be answered:

1. In what level is the problem solving skills of high school students and their parental attitudes?

2. What is the level and direction of the relationship between parental attitudes and students' problem solving skills?

3. Do the parental attitudes predict the problem solving skills of high school students?

\section{Materials and Method}

This research is in a quantitative relational survey model. Relational survey methods are research models used to determine the existence and/or degree of co-change between the two or more variables [20].

\subsection{Participants}

The population of the research is 4850 high school students studying in Diyarbakır/Silvan town center. Because of the difficulty in reaching the target population, time and cost savings, sampling that can represent the population was used.

In the research there are 326 high school students selected randomly from Silvan district in 2015. The data belong to the sample is shown in Table 1.

Table 1. Personal Information Related to the Participants

\begin{tabular}{|c|c|c|c|}
\hline \multirow{4}{*}{ Gender } & & $f$ & $\%$ \\
\hline & Male & 196 & 60,1 \\
\hline & Female & 130 & 39,9 \\
\hline & Total & 326 & 100 \\
\hline \multirow{3}{*}{ Parents together? } & $10^{\text {th }}$ & 315 & 96,6 \\
\hline & Total & 11 & 3,4 \\
\hline & Total & 326 & 100 \\
\hline \multirow{4}{*}{ Mother educational level? } & Primary & 286 & 87,7 \\
\hline & Secondary & 30 & 9,2 \\
\hline & High school & 8 & 2,5 \\
\hline & University & 2 & 6 \\
\hline \multirow{3}{*}{ Grade } & 9th & 276 & 84,7 \\
\hline & 10th & 50 & 15,3 \\
\hline & Total & 326 & 100 \\
\hline \multirow{4}{*}{ Who care for you most? } & Mother & 84 & 25,8 \\
\hline & Father & 184 & 56,4 \\
\hline & Other & 58 & 17,8 \\
\hline & Total & 326 & 100 \\
\hline \multirow{4}{*}{ Father educational level? } & Primary & 180 & 55,2 \\
\hline & Secondary & 101 & 31,0 \\
\hline & High school & 37 & 11,3 \\
\hline & University & 8 & 2,5 \\
\hline
\end{tabular}




\subsection{Data Collection Tool}

In the research, in order to reveal the parental attitudes of high school students, "Parental Attitude Scale" developed by Kuzgun (1972) and revised by Eldeleklioğlu (1996) [21] was used. In the scale there are total 40 items; 15 items in the dimension of Democratic; 15 items in Protective/requestor; 10 items in Authoritarian. The scale is a Likert-type scale ranging from 1 to 5 . The scores of democratic, protective and authoritarian are calculated separately.

The "Problem Solving Inventory" that is applied in order to reveal high school students' problem-solving skills, was developed by Heppner and Peterson (1982) and adapted to Turkish by Taylan [22]. "Problem Solving Inventory" is a 5-Likert type consisting of 35 items. Each item is scored from 1 to 5. In the "Problem Solving Inventory" the items of $5,10,11,12,19,23,24,27,33,34$ and 35 are in the dimension of trust the problem-solving skills; the items of 1 , $2,4,6,7,8,13,15,16,17,18,20,21,28,30$ and 31 are in the dimension of approach-avoidance; the items of 3, 14, 25, 26 and 32 are in personal control dimension. The items of 9 , 22 and 29 were left out the scoring.

Cronbach Alpha internal consistency coefficient of "Parental Attitude Scale" is .89; "Problem Solving Skills Inventory" is .65. It is stated that .60 or higher is considered to be reliable values in social studies [23].

\subsection{Collection and Analysis of Data}

The scales were applied to high school students in the Silvan district. After extracting the four missing data remained total of 326 data for evaluation. In the analysis of the data collected in this research, descriptive statistical techniques (frequency, percentage, mean, standard deviation), cross-correlation and regression analysis were used. In the analysis $p \leq .05$ and $p \leq .01$ levels are based on.

\section{Findings}

Table 2. Descriptive Statistics Concerning the Students' Problem Solving Skills and Parental Attitudes

\begin{tabular}{ccccc}
\hline & Dimensions & N & M & SD \\
\hline \multirow{3}{*}{ Problem Solving Skills } & Trust & 326 & 3,27 &, 57 \\
& Approach-avoidance & 326 & 3,20 &, 42 \\
& Personal control & 326 & 3,01 &, 56 \\
& Total & $\mathbf{3 2 6}$ & $\mathbf{3 , 1 7}$ & $\mathbf{, 3 4}$ \\
\hline \multirow{2}{*}{ Parental Attitudes } & Democratic attitude & 326 & 3,28 &, 81 \\
& Authoritarian attitude & 326 & 2,63 &, 81 \\
& Protective attitude & 326 & 2,91 &, 70 \\
\hline
\end{tabular}

In this section, there are tables showing the types of parental attitudes, the levels of problem solving skills of students, the relationship between parental attitudes and problem solving skills, and prediction of parental attitudes on problem solving skills.

Table 2 indicates that the problem solving skills of high school students in the research is in medium level $(M=3.17)$. The dimensions of the problem solving skills of students are also in medium level; "trust" is $(\mathrm{M}=3.27)$, "approach-avoidance" is $(\mathrm{M}=3.20)$ and "personal control" is $(\mathrm{M}=3.01)$.

The participant high school students' parental attitudes are in medium level; "democratic" attitude is $(\mathrm{M}=3.28)$, "authoritarian" attitude is ( $\mathrm{M}=2.63)$ and "protective" attitude is $(\mathrm{M}=2.91)$. In the parental attitudes, the highest score is in the "democratic attitude", and the lowest score is in the "authoritarian attitude".

Table 3. Relationship between Dimensions of Parental Attitudes and Problem Solving Skills

\begin{tabular}{c|c}
\hline Dimensions of Parental Attitudes & $\begin{array}{c}\text { Problem Solving Skills } \\
(\mathrm{N}=326)\end{array}$ \\
\hline Democratic attitudes &, $43^{* *}$ \\
\hline Authoritarian attitude &,- 020 \\
\hline Protective attitude &, $18^{* *}$ \\
\hline
\end{tabular}

** It shows the significant relationship of 0.01 level $(\mathrm{p}<0,001)$.

Table 3 shows positive medium level correlation $(\mathrm{r}=.43$; $\mathrm{p}<.01)$ between democratic parental attitudes and students' problem solving skills. It can be claimed that the more parents exhibit democratic attitudes in raising their children, the more increase the problem solving skills of the children.

There is no even negative significant correlation between the authoritarian parental attitudes and students' problem-solving skills $(\mathrm{r}=.02 ; \mathrm{p}>.01)$. There is a positive weak correlation $(r=.18, p<.01)$ between the protective attitude of parents and students' problem solving skills.

Table 4. Regression analysis findings related to the impact of parental attitudes on the students' problem solving skills

\begin{tabular}{cccccc}
\hline Predictive Variables & $\mathrm{R}$ & $\mathrm{R}^{2}$ & $\beta$ & $\mathrm{t}$ & $\mathrm{p}$ \\
\hline Democratic attitude & .192 & .137 & .42 & 7.38 & $00^{*}$ \\
\hline Authoritarian attitude & .285 & .103 & -.17 & -2.53 & $.01^{*}$ \\
\hline Protective attitude & .448 & .20 & .09 & 1.30 & .19 \\
\hline $\mathrm{p} \leq .01^{*}$ & & & & &
\end{tabular}

In general parental attitude explain for $20 \%$ of the variability in problem solving skills of high school students. The variables included in the model to predict the problem solving skills are seem to contribute significantly to the model $\left(\mathrm{R}^{2}=.20, \mathrm{p}<0,01\right)$. Among the predictive variables the highest impact is democratic parental attitudes, which has a positive impact $\left(\beta=.42 ; \mathrm{R}^{2}=.14 ; \mathrm{p} \leq .01\right)$. On the other hand, the authoritarian parental attitude has a negative impact $(\beta=$ $\left.-.17 ; \mathrm{R}^{2}=.10 ; \mathrm{p} \leq .01\right)$. However, the protective parental attitudes have no significant impact on the students' problem-solving skills.

\section{Results and Discussion}

This research aiming to demonstrate the impact of 
parental attitudes on high school students' problem solving skills is in relational survey technique of quantitative method. The results reached in the research are as follows:

1. The problem solving skills of high school students participated in the study were found to be at medium level.

2. When asked to the students "who care you most in your educational issues?" they answered as "mostly fathers". This can be resulted from the educational level of the parents. Educational levels of parents are important in children's development. From the students' personal information shown in the study it is seen that the educational level of mothers is relatively much lower than the fathers. Fathers have an important role in the development of child's problem solving skills. Especially boys see their father as a role model [4].

3. There was found a positive medium correlation between the democratic parental attitudes and problem solving skills of the students participated in the study. There was also found a positive low correlation between the protective parental attitudes and problem solving skills of the students. Çelenk [18] also found that the children in protective family environment can succeed in school if they are given suitable care and protection. However, overprotective parental attitudes may cause some problems such as shyness, extreme stubbornness and fear of animals [5]. On the other hand, there was not found any significant correlation between authoritarian parental attitudes and problem solving skills of the participant students.

4. The parental attitudes towards their children predict the problem solving skills of high school students at $20 \%$. The parental attitudes towards students are mostly democratic attitudes, then respectively authoritarian attitudes and they demonstrate protective attitudes at the least frequency. The parental attitude which has positive and the highest impact is democratic parental attitude. Democratic parental attitudes of father will enable the children acquire democratic skills [4]. Research has found that democratic parental attitudes enable high school students to get rid of shyness and acquire positive features such as problem solving skills [24]. Democratic parental attitudes also support children's self-conceptualization [10].

It can be claimed that the impact of the authoritarian attitude is negative. It has been determined that there are significant relations between fear of animals, spitting, lying and strict/authoritarian parental attitudes [5]. It has been also observed that high school students' shyness differentiate in meaningful level according to perceived parent attitudes and it has been found that score averages of students who define perceived parent attitudes as authoritarian are significantly higher than the ones who define as democratic [24].

\section{REFERENCES}

[1] Özkan, F. \& Tösten, R. (2011). İlköğretim I. Kademe Öğrencilere Dini Değerlerin Kazandırılmasında Ailenin Etkisi: Diyarbakır İli Örneği. Eskişehir Osmangazi Üniversitesi Değerler Eğitimi Sempozyumu (26-28 Ekim), Eskişehir.

[2] Starkey, P., \& Klein, A. (2000). Fostering parental support for children's mathematical development: An intervention with Head Start families. Early Education and Development, 11(5), 659-680.)

[3] Oundo, E. N., Poipoi, M. W., \& Were, D. S. (2014). Relationship between Parents' Attitude towards Educational Involvement and Academic Performance of Day Secondary School Students in Samia-Kenya. International Journal of Human Resource Studies, 4(3), 147.

[4] Eskicumal1, A., \& Eroğlu, E. (2001). Ailenin sosyo-ekonomik ve eğitim düzeyleri ile çocukların problem çözme yetenekleri arasındaki ilişki. Sakarya Üniversitesi Eğitim Fakültesi Dergisi, (1).

[5] Derman, M. T., \& Başal, H. A. (2013). Okulöncesi Çocuklarında Gözlenen Davranış Problemleri ile Ailelerinin Anne-Baba Tutumları Arasındaki İlişki. Amasya Üniversitesi Eğitim Fakültesi Dergisi, 2(1), 115-144.

[6] Aktaş, S. (2011). 9. sınıfta anne baba tutumları ve benlik saygısı arasındaki ilişkinin bazı değişkenler açısından incelenmesi. Doctoral dissertation, Selçuk Üniversitesi Eğitim Bilimleri Enstitüsü.

[7] Yıldırım, A. (2005). Kurum bakımında olan ve ailesi ile birlikte kalan 13-18 yaş arası çocuklarda sürekli öfke ile depresyon düzeyleri arasındaki ilişkinin incelenmesi. Yayınlanmamıș Yüksek Lisans Tezi, Fırat Üniversitesi Sağlık Bilimleri Enstitüsü, Elazı̆̆.

[8] Aydoğmuş, K. (2001). Çocuklarda Uyum ve Davranış Bozuklukları. Ana-Baba Okulu. İstanbul: Remzi Kitap Yayıncilik.

[9] Uzuner, Y. (2003). Çocukta Ruh Sağlığı, Uyum Bozukluğu. Ailede Ruh Sağlığı (ed. Y. Uzuner). Eskişehir: Açık öğretim Fakültesi Yayınları, 45-56.

[10] Sezer, Ö. (2010). Ergenlerin Kendilik Algılarının Anne Baba Tutumları ve Bazı Faktörlerle İlişkisi (ss. 1-19). Yüzüncü Yı1 Üniversitesi Eğitim Fakültesi Dergisi, 7(1).

[11] Akbaba, S. (2004). Psikolojik sağlığı koruyucu rehberlik ve psikolojik danışma. PegemA Yayıncılık, Ankara.

[12] Totan, T., \& Yöndem, Z. D. (2007). The investigation of bullying in adolescence related to parent and peer relations. Ege Eğitim Dergisi, 8(2), 53-68.

[13] Yavuzer, H. (2004). Ana-Baba ve Çocuk. 17. Basım, İstanbul: Remzi Kitabevi.

[14] Baumrind, D. (1966). Effects of authoritative parental control on child behavior. Child development, 887-907.

[15] Maccoby, E. E., \& Martin, J. A. (1983). Socialization in the context of the family: Parent-child interaction. Handbook of child psychology: formerly Carmichael's Manual of child psychology/Paul H. Mussen, editor. 
[16] Küpçü, A. R. (2012). Etkinlik temelli öğretim yaklaşımının orantısal akıl yürütmeye dayalı problem çözme başarısına etkisi. Ahi Evran Üniversitesi Kırșehir Eğitim Fakültesi Dergisi (KEFAD) Cilt 13, Sayı 3, Aralık 2012, Sayfa 175-206.

[17] Jencks, C. (1972). Inequality: A reassessment of the effect of family and schooling in America. http://eric.ed.gov/?id=ED077551.

[18] Çelenk, S. (2003). Okul başarısının ön koşulu: Okul aile dayanışması. İlköğretim online, 2(2).

[19] Satır, S. (1996). Özel Tevfik Fikret Lisesi öğrencilerinin akademik başarılarıyla ilgili anne baba davranışları ve akademik başarıyı artırmaya yönelik anne-baba eğitim gereksinmelerinin belirlenmesi. Yayınlanmamış. Yüksek Lisans Tezi. A.Ü Sosyal Bilimler Enstitüsü.
[20] Karasar, N. (2007). Bilimsel Araștırma Yöntemi. Ankara: Nobel Yayın Dağıtım Ltd. Şti.

[21] Kuzgun, Y. \& Bacanl1, F. (2005). PDR'de Kullanılan Ölçekler. Ankara: Nobel Yayın Dağıtım.

[22] Taylan, S. (1990). Heppner'in Problem Çözme Envanteri'nin uyarlaması, güvenirlik ve geçerlik çalışması. Unpublished master's thesis, Ankara Üniversitesi, Ankara.

[23] Can, A. (2014). SPSS ile Bilimsel Araştırma Sürecinde Nicel Veri Analizi, Pegem Akademi, Ankara

[24] Hamarta, E., Baltacı, A. G. Ö., Ömer, Ü. R. E., \& Demirbaş, U. P. D. E. (2010). Lise öğrencilerinin utangaçlıklarının algılanan anne baba tutumları ve problem çözme yaklaşımları açısından incelenmesi. Sosyal Politika Çalışmaları Dergisi, 21(21). 